$\begin{array}{llll}\text { 田 } & \text { 中 } & \text { 啓 } & \text { 策 }^{* *} \\ \text { 松 } & \text { 本 } & \text { 達 } & \text { 郎 } \\ \text { 前 } & \text { 田 } & \text { 保 } & \text { 夫*** }\end{array}$

\title{
The Izami Group in the Southernmost Part of the Island of Awaji
}

by

\author{
Keisaku TANAKa, Tatsuro MATsumoto \& Yasuo MAYedA
}

(Résumé)

The Island of Awaji in Hyogo Prefeeture is occupied in its southern part by the upper Cretaceous Izumi group and is famous for the occurrence of the interesting fossils. The hitherto described fossils, however, were mainly derived from the lower half of the group. The writers recently surveyed through the Cretaceous area and especially made a detailed work on the southern steep slopes of the island, with the results that a fossiliferous membar was discovered near the uppermost part of the group and that the stratigraphy of the upper half was considerably revised. The emended stratigraphic szquence of the Izumi group in this island is as follows in ascending order:

1. Tsui basal conglomerate, 200 meters thick.

2. Minato shale, vary fossiliferous, $500 \mathrm{~m}$.

3. Yoroizaki sandston3, with subordinately interbedd $ə d$ shale, $1,400 \mathrm{~m}$.

4. Shichi shal 3, fossilifarous, $400 \mathrm{~m}$.

5. Kitaama sandstone and shale (emended) : Thick series of alternating sandstone and shal $, 3,300$ $\mathrm{m}$. Thə sandston 3 is predominant in thə lower part, whəreas the shale is predominant in the upper part. Layers of liparitic tuff are intercalated at horizons snd esp scially remarkable in the lower part. Fossils occur sporadically from the sandstone of the quarries.

6. Nada sandstone and conglomerate (emended): Sindston? with interbedded shale and conglomerate, $1,100 \mathrm{~m}$.

7. Shimonada fin ?-sandy siltston?. containing nodul as and fossils abundantly. $370 \mathrm{~m}(+)$.

8. Shimonada white sandstone, with sporadic fossils, $250 \mathrm{~m}(+)$.

Layers of tuff are intercalated in members ( 7 ) and ( 8 ).

The identified fossils derived from the upprr half (i. e. $5 \sim 8$ ) are listed in the table of th? Japanese text. From these fossils the uppir half of the group is safely correlated to the upper Hetonaian in Hokkaids, the approximate equivalent of the uppermost Senonian of Europe, and is a representative of the uppermost Cretaceous in Southwes, Japan.

Together with the stratigraphy some interesting features of the geologic structure in the southernmost part of the island are described. (See the annexed geologic map.)

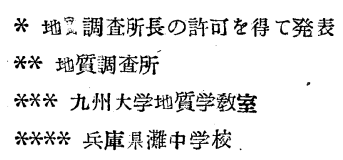

地学㮅誌 Vol. 61, No. 2 (684), 1952

\section{ま えがき}

淡路島の和泉層洋については江原真伍拉よび篗井博一 の研究があり, また 1947 年に東中秀雄仕同島最南部に 招いて, 和泉層群と鮮新一更新統とを界するスラストを 発見した。田中は 1949 年に地質調査所施行の 7 万 5 千 分の 1 「徳島図幅」に扔いて淡路島南部の地質調査を行 い,その結果和泉膡群の層序扔よび地質構造について新 
しい事契を知ることができた。その後前田もこの地域の 和泉置群を調査し同時に多数の化石を採集し，またその 化石を松本が鑑定して新しい知識を増した。

その結果淡路島の和泉層群の㬝序は和泉虐群全般の標 準層序を示し, 同島の和泉層群最上部は, 西南日本に招 いて化石から確認された唯一の最上部白瑟系,すなわち ヘトナイ統上部階であることが判っだ。以下主として新 たに得られた知識について述べる。

\section{層序}

淡路島の和泉層群の層序は一応䈎井によって確立され
たがここでは笹井による層序を幾分訂正して記述する。 その層序は上位から下位へ次の通りであって, おの扔の の関係は整合である。

8 ）下灘白色砂岩層（新称）：白色砂岩を主として凝灰 岩を摤を。厚さ約 $250 \mathrm{~m}$ 以上

7 ）下灘細砂質シルト岩層（新称）：主にシルト質細砂 岩乃至細砂質シルト岩から成り凝灰岩を摤み, 団萝 扣よび化石に富も。厚さ約 $370 \mathrm{~m}$ 以上

一断層関 係—

6 ) 灘砂岩砅岩層（修正）：砂岩を主とする砂岩・砶岩・

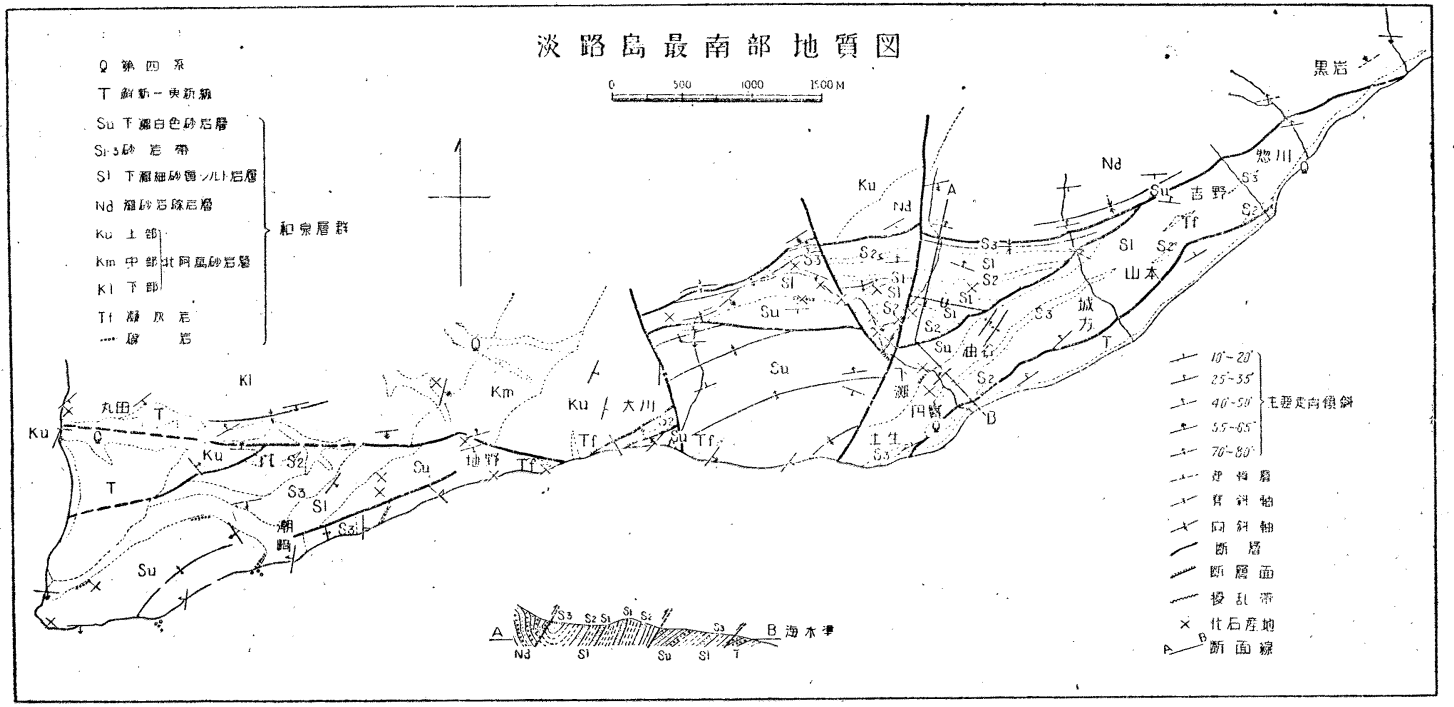

頁岩互層, 厚さ約 $1,100 \mathrm{~m}$ 以上

5 ) 北阿万砂岩頁岩層 (修正)

上部：此較的頁岩に富む沙岩・真岩互罣から成り凝 灰岩を挾さP。厚さ約 $600 \mathrm{~m}$

中部：砂岩を主とし凝灰岩を扶さ。厚さ約 $200 \mathrm{~m}$

下部：主に砂岩に富さ㠺岩・頁岩互層から成り, 藷 しい凝灰岩を捬む。厚さ約 $2,500 \mathrm{~m}$

4) 志知面岩層 : 厚さ約 $400 \mathrm{~m}$

3 ) 鎧崎砂岩層 : 砂岩に富を砂岩・面岩互層, 厚さ約 $1,400 \mathrm{~m}$

2) 澿面岩層 : 厚さ約 $500 \mathrm{~m}$

1) 津井基底碩岩瀗: 厚さ的 $200 \mathrm{~m}$

上記の層序に扔いて新しくわかった点は, 徒来の北阿 万秒岩層扣よび灘放岩磁岩層両者を修正し，かっ從来の 層序に最上位の地層として新称の下灘細杪質シルト岩層 および下灘白色㫾岩層を附け加えたことでもる。但し灘 砂岩䃯岩層（修正）下灘細砂質シルト岩層両者は断闃関
係にもる。以下主として下灘細紗質シルト岩層扣よび下 灘白色砂岩層について述べる。

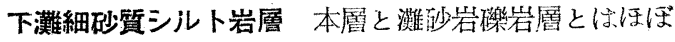
東西方向の大断層によって接するために，両尿の㺟位的 関係は不明じある。然し後述するように淡路島の和泉層 群は大局的にみると単斜棈造をなして扣り，かっ本層を 構成するよろな岩相がこの断層の北側において断層から 余り遠くない所にみれないので，本層は灘砂岩礫岩層の

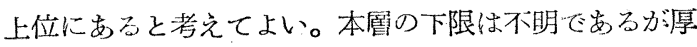
さは約 $370 \mathrm{~m}$ 以上と推定され各。主に暗灰色塊状のシル 下澌細砂岩乃至細砂質シル卜㞸から成り，石灰質扣よび 泥扊岩の団塊を多く含久菊石類・イノセラムスその他の

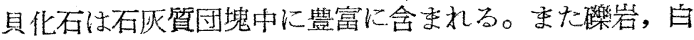
色中粒砂岩, 頁岩, 砂岩, 頁岩互層扣よで凝灰岩を扶さ。 白色秒岩に富毛部分は 3 帯にわたって摤在し, その中最 上位のものが最も厚くその厚さは約 $70 \mathrm{~m} て ゙$ そて, 他 の2帯は 20〜 40 mである。この3帯地質図に扣いて $\mathrm{S}_{1}, \mathrm{~S}_{2}$ 扣よび $\mathrm{S}_{3}$ の記号をもって記入されている。次 
に本層の標式的層序を示す。 灘村円実に注ぐ沢の東方の枝沢

6 ) 塊状中粒砂岩。厚さ約 $20 \mathrm{~m}$ 以上 $\left(\mathrm{S}_{3}\right)$

5 ）塊状シル卜質細砂岩方至細砂質シルト岩。厚さ約 $100 \mathrm{~m}$

4 ) 塊状中粒砂岩を主として砂岩・頁岩互層を伴う。厚 さ約 $30 \mathrm{~m}\left(\mathrm{~S}_{2}\right)$

3 ) 塊状シルト質細杪岩乃至細砂留シルト岩を主とし て, 塊状中粒砂岩を伴 弓。厚さ約 $20 \mathrm{~m}$

$2)$ 塊状中絃砂岩。厚さ約 $20 \mathrm{~m}\left(\mathrm{~S}_{1}\right)$

1 ) 塊状シルト質細抄岩万至細砂質シルト岩を主として 砂岩・頁岩互層を伴い，また下部には厚さ約 $10 \mathrm{~m}$ の頁岩を摤さ。厚さ約 $40 \mathrm{~m}$ 以上

灘村湖猗 (部落)

7 ）塊状シルト質細砂岩乃至細砂質シルト岩。厚さ約 $90 \mathrm{~m}$

6 ) 增状中粒砂岩を主として，厚さ約 $20 \mathrm{~m}$ の礫岩をレ ンズ状に㣣む，厚さ約 $70 \mathrm{~m}\left(\mathbf{S}_{3}\right)$

5 ）塊状シル卜質細少岩乃至細砂質シルト岩。

下灘白色砂岩胥 本層は下位の下灘細仯質シルト岩層 とは整合的関係にあって, 上限は不明で专るが厚さは約 $250 \mathrm{~m}$ 以上推定己れる。主に塊状時には成層していて ，中锌時には粗粒となる砂岩から成る。この䏚岩は風化 のために白色を呈することが多いが，元来は淡褐色を旺 するようである。この点和泉蕒群を特徵づける緑灰色少 岩と異なる。末た顕微鏡下では構成鉣物に新蟹な長石類 が多く, 新掣な黑雲母が多少みとめられ, かっ緑泥石は 稀ごある。これに反して緑灭色少岩の構成鉣物こは新䦅 な長石類が少なく，黒雲母としてみとめられるものが殆 んどなく, 緑泥不が多い。また火山岩質の組織を示寸部 分もまる。石英の量は両者とは余り差異はない。な扣本 層の砂岩は有機質の微片を多量に含もことが多い。部分 的には暗灰色細粒砂岩, シルト質細砂岩乃至細砂質シル 卜岩を伴弓。また硯岩, 砂岩・頁岩互層, 泥岩, 頁岩, 凝

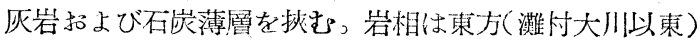
から西方（大川以西）に向って細粒となり，東方では砂 岩は塊状のものが多いが西方では成買のものが多くな り，末た泥岩質扔よびシルト岩質つものが多く挾生する よらになる。基底にはレンズ㧋に消曼する厚さ 2 〜 $3 \mathrm{~m}$ 以下の磞岩り至極めて粗粒の砂岩があって, この基底部 扣よび少し上位からは比較的多数の化石が侜出する。

\section{※比及び地買時代}

前記の北阿万砂岩真岩層（修正）扢よび灘沙岩磁岩層 (修正) は，それぞれほぼ谁打の两層の招の招のに対比

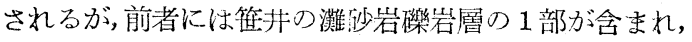

また後者は笓井の灘砂岩砶者層中の 1 部すなわら砂岩报

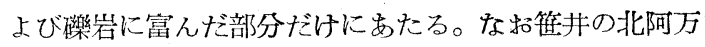
砂岩層扣よび灘砂岩礫岩層の各 1 部は下灘細砂質シルト 岩層和よび下灘白色砂岩層として区別され，この両層は 淡路島の和泉層群の最上部を占める。北阿万砂岩頁岩層, 下灘細㫾質シル下岩層扣よび下灘白色砂岩層から産出し た化石は後表の通りである。この表からかかるように， 下灘細砂質シルト岩層扣よび下灘白色砂岩層の時代は人 トナイ世新期であって, 北阿万砂岩頁岩層の時代も材料 がやや不足ではあるがートナイ世新期であると考学てよ い。な扣瓷頁岩層扣よび志知頁岩層はその化石内容加ら みると, 両層の時代はいづれもへトナイ世古期と考える ことが妥当である。往って淡路島の和泉層群の時代は大 体へトナイ世で女って, 唯最下部だけが浦河世末覀期で あるか子知れない。

\section{地 質 構 造}

淡路島南部に発達する構造には, 成生頉序の古いもの から記すと次のよらなものがある。

1) 和泉層群と淡路島南方の沼島を構成する三波川変成 岩類との間を通るいわゆる中央構造線, および和泉 層群の全般的な同斜構造と主向科構造（主向斜構造 は淡路島ではみとめられない。）

恐らく由聖紀直後から第三紀初期に成生

2a）和泉層群の見掛上の水平移動による屈曲扣よびそれ に伴って成生した南北に近い力向の主断層群（例え ば猪つ悬一白崎間及び湊一本庄間を通る断㬝）括よ び随伴断尿群と小裮曲構造

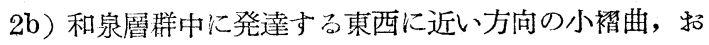
よび断層とそれに伴ら南北に近い力向の断層群

以上鮮新一更新統堆積前の成生

3 ) 和泉層样と鮮新一更新統との間を通る衝上断層 蘚新一更新統倠積後の成生

上記の棈造の中, 従来の知識に新たに附け加えられた ことは (2b) の構造が存在することである。(2a)の猪，

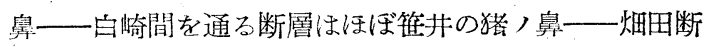
屠線に相当するが, 後者の断層の南端が畑田にはなくて さしろ白崎附近にあって, ここでは走向 $\mathrm{N} 10^{\circ} \mathrm{E}$, 傾 斜東へ $70^{\circ}$ の断層がみられる。湊一一本庄間を通る断層 は笹井の湊一本庄断層線つことを指している。（2れ）扰 よび (2b) の構造はいづれるほぼ同時に成生したもので あって, 西南日本内带に招いて広範囲に分布するいわゆ る鮮新一一更新統の堆積盆地をつくつた構造の 1 部でも ろち。その中 $(2 \mathrm{~b})$ の断層は四国松山附近に扣ける和泉 㢞群と石槌山新第三系とを界する砥部のスラストと, 添 ぼ同時に成生したものだると考えられる。また( 3 )の 
淡路島和泉層群上半部産化石表

List of fossils from the upper half of the

Izumi group in the Island of Awaji

\begin{tabular}{|c|c|c|c|c|c|c|}
\hline \multirow{2}{*}{$\begin{array}{llll} & \text { 産 出 地 層 Horizones } \\
& & & \\
& \text { 化 } & \\
\end{array}$} & \multicolumn{2}{|c|}{\begin{tabular}{c|} 
( 5 北阿万砂岩頁岩層 \\
\end{tabular}} & \multirow{2}{*}{$\begin{array}{l}\text { (6) } \\
\text { 灘 砂 岩 } \\
\text { 磇 岩 層 }\end{array}$} & \multirow{2}{*}{$\begin{array}{l}\text { (7) } \\
\text { 下灘細砂 } \\
\text { 質 } ル \text { 小 } \\
\text { 岩層 }\end{array}$} & \multirow{2}{*}{$\begin{array}{c}\text { ( } 8 \text { ） } \\
\text { 下灘白色 } \\
\text { 砂 岩 層 }\end{array}$} & \multirow{2}{*}{$\begin{array}{l}\text { Hetonaian } \\
\text { 北海道樺太 } \\
\text { ヘトナイ統 }\end{array}$} \\
\hline & 下 部 & 上 部 & & & & \\
\hline Acila sp & & & & $x$ & . & \\
\hline $\begin{array}{l}\text { Nuculana (Ezonuculanx) mactraeformis } \\
\text { NAGAO }\end{array}$ & & & & & $x$ & \\
\hline Grammatodon sach linensis (SCHMIDT) & . & & & $(x) \mathbf{C}$ & & $x$ \\
\hline G.elongatvs (NAGAO \& OTATUME) em & & & & $(x) \mathbf{C}$ & & $x$ \\
\hline $\begin{array}{l}\text { Inoceramvs shikotanensis NAGAO \& MA- } \\
\text { TSUMOTO }\end{array}$ & $\times \mathbf{C}$ & & & & & $x$ \\
\hline I. aff. ezoensis YOKOYAMA & & $(x)$ & & & & \\
\hline I. b.lticus Вонм (immature) & $x$ & & & & & \\
\hline I. cfr. heton ianus MATSUMOTO & & & $\times ?$ & $\times ?$ & & $x$ \\
\hline I. awajiensis MATSUMOTO & & & & $\times \mathbf{C}$ & $x$ & $\times ?$ \\
\hline Ostrex sp. & $x$ & & & & & \\
\hline Exogyra sp. & . & & & & $x$ & . \\
\hline Modiola sp. & & & & & $x$ & \\
\hline Laternula (?) sp. & & & & $x$ & & \\
\hline Periplomya elliptica NAGAO \& OTATUME & & & & $(x)$ & & $x$ \\
\hline Thracia sp. & & & & & $x$ & 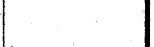 \\
\hline Dosiniopsis sp. & & & & $\times \mathbf{C}$ & $\times$ & \\
\hline Aphrodina pseudoplana (YABE \& NAGAO, & & & & & $(x)$ & $x$ \\
\hline $\begin{array}{l}\text { Helcion (?), problematicus NAGAO \& } \\
\text { OTATUME }\end{array}$ & $x$ & & & & & $x$ \\
\hline $\begin{array}{l}\text { Neophylloceras cfr. hetonaiense MATSU- } \\
\text { MOTO }\end{array}$ & & & & $x$ & & $x$ \\
\hline $\begin{array}{l}\text { Canadocoras(?) cf. multicostatum MA- } \\
\text { TSUMOTO }\end{array}$ & & & & $(x)$ & & $x$ \\
\hline $\begin{array}{l}P{ }^{\top} \text { chydiscus(s.s) subcompressum MATSU- } \\
\text { MOTO }\end{array}$ & & & & $\times \mathbf{C}$ & & $x$ \\
\hline Baculites cfr. vina FORBES & $x$ & & & & & \\
\hline Rhychonella cfr. plicatiloides STOLICZkA & & & & & $\times G$ & $x$ \\
\hline Echinoid & $\times$ & & & & $\times 0$ & $\lambda$ \\
\hline Coral & & & & $x$ & & \\
\hline Plagioloplus ezoensis NAGAO* & & & & & $\times \mathbf{C}$ & $x$ \\
\hline Callicnassa ezoensis NAGAO* & & & & & $\times$ & $x$ \\
\hline Archreozostera sp. & $\times \mathbf{C}$ & & & & & \\
\hline
\end{tabular}

（×）転石として採集されたが産出地層の明らかなもの

$\times$ ? 産出地層の明らでないるの

C 普通 (Common) 飞産出するすの

* 今泉力蔵の鑑定による 
断層は和洜山脈東部に招けそ和泉層群々菖蒲谷層(ほほ 淡路島の鮮新一一更新統に対比される) とを界する菖蒲

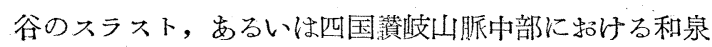
層群と古期洪積層とを界するスラストと，ほぼ同時に成 生したものであると考えられる。な特 ( $2 \mathrm{~b}$ ) の断層によ って現在の淡路島南縁にみられる断層海岸地形の原形が つくられたと相像される。

淡路島の和泉層群は大局的にみると, $\mathrm{NE}-\mathrm{SW}$ の走 向を有し約 $30^{\circ} \sim 50^{\circ}$ 南東に倾斜するが, 同島最南部で は譛曲扔よび断層がよく発達する。灘村黑岩から阿万町 丸田間を通る大きな断層があって, それは恐らくスラス ト乃至それに近いるのと思われる。この断尿をここでは 灘断層と称して，それは大川を通る NNW一SSE 方向 の断尿によって切られる。灘断層の北側にほ北阿万砂岩 頁岩層扔よび灘砂岩砅岩層が分布して扔り，南側には主 に下灘細砂質シルト岩贋扣よび下灘白色砂岩層が分布し ている。

灘断層の北側に分布する地層は黒岩附近では逆転し, 城方北方では向斜構造をなし，円笑北方では逆転してい る。更にその西扣よび大川附近では単斜構造をなしてい るが, 丸田東方では向斜構造をなしている。

灘断層の南側に分右する地層は, 大川を通る NNW一 SSE 方向の断層によって2つの区域に分かれる。その 中東方の区域では灘断層の南側にそれと同種の断層が通 り,この断層をここでは下灘断層と称する。灘, 下灘両 断層は NE-SW 扣よび NW-SE 万间の2断層によ って切られる。従って東方の区域は6つのブロックに分 たれ，地尿は振幅の小さい袼曲をなしている。北側の 3 つのブロックでは地層は背斜構造をなし, 灘断畨に近い 所では更に小さい向斜構造をなしている場合がある。こ の 3 ブロックの中西方のもの程相対的に落下している。 すなわち東方のブロックでは, 下灘細砂質シルト岩曆中 の $\mathrm{S}_{1}$ より下位の地層が軸部を占め, 中央のブロックで は $\mathrm{S}_{1}$ 、 も軸部をなしているが，西方のブロアクでは $\mathrm{S}_{3}$ が軸部をつくっている。な招東方のブロックでは背斜軸 は北方へ転倒している。南側の3ブロックの中東方のブ ロックでは, 下灘細所質シルト岩尿扔よび下灘白色砂岩 層が北へ傾斜し，油谷北方では局部的な 1 小背斜扣よび 1 小向斜構造が女る。屯た吉野一土土生間では和泉層群 が蘚新一一更新統に衝上する。この衝上断層を油谷衝上 断層と称し, 油谷にて観察される。ここでは断層面の走 向は $\mathrm{N} 50^{\circ} \mathrm{E}$ で, 傾斜は $\mathrm{NW} 35^{\circ}$ であって, その面

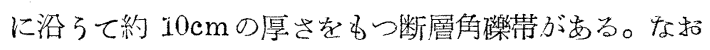
この断層は円実附近て段丘堆積物て覆われているようで ある。中央の極めて小さいブロックでは下灘白色砂岩層 が分布し，その走向は一定していないが傾斜は一般にS
Eあるいは SW 方向である。西方のブロックでは下灘 白色砂岩層が 1 背斜扣よび 2 向斜棈造をつくり, かっ下 灘断層に近い所に゙は小さ背斜盽造をなしいる。

西方の区域の中大川附近では下灘断層の延長によって 南北の両ブロックに分かれ，前者に拈いては下灘細砂質 シルト岩層が分布し, 後者に拁いては下灘白色砂岩層が 分存寸る。いづれも走向呿よび傾斜方向は一定していな いが傾斜は一般に NE 乃至 NW 方向である。大川以 西では丸田南方に扣いて灘断層の南側にこの断層と同種

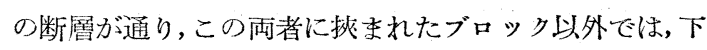
灘細砂啠シルト岩層执よび下灘白色砂岩層が分布する。 ここでは 1 向斜構造扣よび 1 背斜構造があって, 湖渏 (部落) では下灘細砂質シル卜岩畨の $\mathrm{S}_{3}$ が背斜の軸部 をなしている。

江原は淡路息の和泉層群は 1 つの大き向斜構造をな していると考えたが，笩井は大局的にみると整然とした 単斜構造をなしていると考えた。ここではもしろ後者の

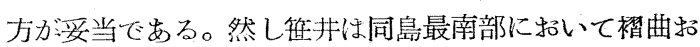
よび断層が発達していることを指摘しなかったが，これ に反して江原は间斜軸に沿らて相川一一阿万断䚄線が通 ることを指滴した。この断層は前述の黒岩一丸田間を 通る灘断層にほぼ相当するものである。

\section{むすび}

以上に述ベたことから新たに判明した事実について記 于。

1) 従来の北阿万砂岩層扔よび灘砂岩礫岩層を訂正し, かっ和泉層群の最上部に下灘細沙質シルト岩層执よび 下灘白色砂岩層老設けた，その中下灘細沙質シルト岩 層は一トナイ統上部階を指示する化石を豊富に産出す る。これら諸阔は西日本に拈ける同階の代表層である。 2) 淡路岛最南部の和泉層样には裮曲扣よび断層（衝上． 断層乃至それに近いもの) が発達する。

3 ) 北阿万砂岩頁層下部, 中部, 下灘細抄質シルト岩層 扣よび下灘白色抄岩層には, 厚さ $10 \mathrm{~m}$ 以下の流紋岩 質凝灰岩が拢在する。

要するに淡路島に拈ける和泉層群の層序は, 和泉層群 全般の標式的尿序を示すものであって, 下灘細砂質シル 卜岩層扣よび下灘当色砂岩畨に対比される地層が，今後 特に化石によって他地域の和泉層群から発見されること が期待される。

\section{附. イノセラムス新種について ?}

ヘトナイ統上部階に特徽的なイノセラムスのろち, 次 の2種は今まで記載が行われていない。他日松本が正式 の記戴をするが，ここには要点だけ摘記して挍く。 
Inoceramus awxjiensis MATSUMOTO(第1困) 小型, Inoc. naumanni YOKOYAMA に一見似て, 綐長いが, 幼時の形が Inor. hetonxianus に似ている。 輪廓が卵形である。賏表面は細か心 concentrric ring で特徵づけられる。

淡路の下灘細砂質シルト岩層に多産。

Inoceramus hetonaianus MATSUMOTO(第2図) 比較的小型, Inoceramus n:um?nni YOKOYAMA に似た点があるが， hinge-line がそれより明らかに長 く, wing も明らかである。輪廓がむしろ三角形で後腹 方に拡った形をなす。やや強い concentric ring のほ かに, 低い concentric undulation があるが, 後者は 弱化の傾向が著しい。かなり变異があり, lnoc. awajiense に形態の近づいたるのが汉とめられる。北海道函淵 層群上部に多産, 似たものは淡路の和泉層群上半にも出 た。

白瑟系最未期のこの 2 種が，かえつて原始的の種類に 見掛上似ていて, 小型で単純な装飾しかないことは興味 樑い。

第 1 図

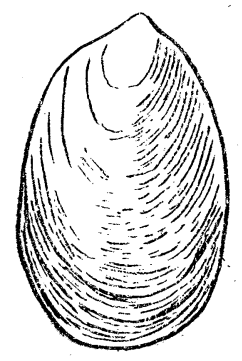

第 2 図

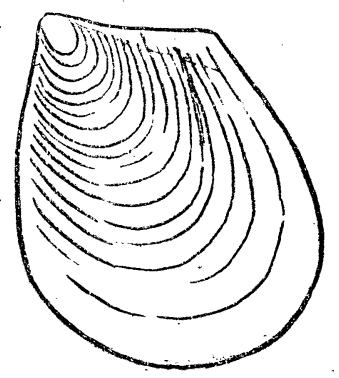

引用文献

東中秀雄, 1951 : 淡路炭田中部及び南部地区調查報告, 地質調查所月報, Vol. II, No. 1

江原真伍, 1920 :四国及び淡路の白瑟紀層について, 地

質学雑誌 Vol XXVII, No. 326

", 1925 : 和泉砂岩層について, 地球, Vol.IV,

No. 5

" , 1945, 太平洋の地款運動, 積善館

河田喜代助, 1939 : 紀ノ川流域の中央線飞沿 5地質, 久

部教授還曆記念論交集, Vol. I

小林貞一, 1931 : 和泉山脈の和泉砂岩層, 地質学雑誌,

Vol. XXXVIII

笙井博一, 1936 : 淡路島の和泉砂岩層, 地質学雑誌,

Vol. XLIII, No. 55

中野光雄・今村外治, 1950 : 讃岐山脈中部の地質特飞最

新世の衝上断層飞就いて (要旨), 地質学雑誌, Vol.

LVI, No. 656

中野光雄, 1951 : 讃岐山脈中部の和泉砂岩層 (特飞層序

と構造) (要旨), 地質学雑誌, Vol. LVII, No. 638

平以健・田中啓策, $1951 ： 1 / 75,000$ 徳島茴幅及び同説 明書 (未刊)

松本達郎・前田保夫, 1951 : 淡路産菊石, パッキディス カス, 地質と鐄物, Vol. IV, No. $3 \sim 4$

Yabe, H ; 1901 : Note on three upper Cretaceous Ammoites from Japan outside of Hokkaido, Jour. Geol. Soc. Tokyo, Vol. VIII

Yabe, $\mathrm{H} ; 1915$ : Note on some Cretaceous fossils from Anaga on the Island of Awaji and Toyaj in the Province of Kii. Sci. Rep. Tohoku Imp. Univ.; 2 nd. Ser.; Vol. IV, No. 1

\section{会貝各位へ御願い}

甚だ申し兼ねますが，本年度（27年度）の会費を至急納大下さる様，切卸願い申上げます。 種々御都合もでざいましよろが，御承知の様江本協会は会費が財源でありますので，会費の納入 の不良は直ち劦会の運営に関係し，雑誌の発行も出来なくなる恐れが多分汇あります。民゙うか 協会の窮状を御察し下さいまして，ての際ぜひ御納大方御配慮願い上げます。

な扣 26 年度までの会費未納の方は，特にとりまとめ納入下されば幸甚ですが，多額の場合は 分割払でも結構ですから御配慮下さい。

\section{会費 23 年度 225 円， 21 年变 300 円， 25年度以降 500 円}

会費納入には振替を御利用下さん。（振替番号, 東京 66278 番 